\title{
Ecological effects of scrubber water discharge on coastal plankton: Potential synergistic effects of contaminants reduce survival and feeding of the copepod Acartia tonsa
}

Koski, Marja; Stedmon, Colin; Trapp, Stefan

Published in:

Book of Abstracts Sustain 2017

Publication date:

2017

Document Version

Publisher's PDF, also known as Version of record

Link back to DTU Orbit

Citation (APA):

Koski, M., Stedmon, C., \& Trapp, S. (2017). Ecological effects of scrubber water discharge on coastal plankton: Potential synergistic effects of contaminants reduce survival and feeding of the copepod Acartia tonsa. In Book of Abstracts Sustain 2017 [A-9]

\section{General rights}

Copyright and moral rights for the publications made accessible in the public portal are retained by the authors and/or other copyright owners and it is a condition of accessing publications that users recognise and abide by the legal requirements associated with these rights.

- Users may download and print one copy of any publication from the public portal for the purpose of private study or research.

- You may not further distribute the material or use it for any profit-making activity or commercial gain

- You may freely distribute the URL identifying the publication in the public portal 
Ecological effects of scrubber water discharge on coastal plankton: Potential synergistic effects of contaminants reduce survival and feeding of the copepod Acartia tonsa

\author{
*Marja Koski, Colin Stedmon, Stefan Trapp \\ *Corresponding author email: mak@aqua.dtu.dk
}

To meet the oncoming requirements for lower sulphur emissions, shipping companies can install scrubbers where the exhaust is sprayed with seawater and subsequently discharged to the sea. The discharge water has a $\mathrm{pH}$ around 3 and contains elevated concentrations of vanadium, nickel, lead and hydrocarbons. We investigated 1) the threshold concentrations and exposure times of scrubber discharge water for survival, feeding and reproduction of the copepod Acartia tonsa, 2) whether the effects depend on the exposure route and 3) whether exposure to discharge water can be detected in field-collected organisms. A direct exposure to discharge water increased adult copepod mortality and reduced feeding at metal concentrations which were orders of magnitude lower than the lethal concentrations in previous single-metal studies. In contrast, reproduction was not influenced by dietary uptake of contaminants. Scrubber water constituents could have synergistic effects on plankton productivity and bioaccumulation of metals, although the effects will depend on their dilution in the marine environment. 